\title{
New Transatlantic African Writing: \\ Translation, Transculturation and Diasporic Images in Chimamanda Ngozi Adichie's The Thing Around Your Neck and Americanah'
}

\section{Elena Rodríguez Murphy}

Described as one of the leading voices of her generation, Nigerian writer Chimamanda Ngozi Adichie has become one of the many African authors who through their narratives have succeeded in challenging the literary canon both in Europe and North America while redefining African literature from the diaspora. Her specific use of the English language as well as transcultural writing strategies allow Adichie to skilfully represent what it means to live as a "translated being". In her collection of short stories, The Thing Around Your Neck (200g), and her latest novel, Americanah (2013), which were greatly influenced by her own experiences as what she has referred to as "an inhabitant of the periphery", Adichie depicts the way in which different Nigerian characters live in-between Nigeria and America. In this regard, her characters' transatlantic journeys imply a constant movement between several languages and cultural backgrounds which result in cultural and linguistic translation.

\section{Keywords}

Anglophone African literature; translation; transculturation; diaspora; Chimamanda N. Adichie; The Thing Around Your Neck; Americanah

Since the end of the twentieth century, the Western literary scene has witnessed an increasing decentralization of traditional literary canons both in reading and writing as well as in the editorial industry. Indeed, while no African writer had won the Nobel Prize in Literature before the 1980s, at that point in time things began to change. From the 1980 os onwards, African authors such as Wole Soyinka (1986), Nadine Gordimer (1991) and J.M. Coetzee (2003) have been Nobel laureates. Moreover, since the 1970s, the Man Booker Prize has been granted to several African writers: the South Africans Nadine Gordimer 
(1974) and J.M. Coetzee $(1983,1999)$, and the Nigerian Ben Okri (1991). It becomes apparent, therefore, that the English literary canon has been, and continues to be, greatly modified by varied narratives written by African authors in the English language.

As Hale underlines in his article "Bursting at the Seams: New Dimensions for African Literature in the $21^{\text {st }}$ Century", although "African writers have been writing from positions outside of Africa from the early part of the $20^{\text {th }}$ century" (18), the newer generation of authors is now reshaping and renewing the literatures of Europe and North America from different perspectives while extending the range of African literature globally. Nigerian-born Chimamanda Ngozi Adichie belongs to this newer generation that, as Hale mentions, is currently restructuring and broadening the Western literary canon in diverse ways. Adichie has by now become one of the most talked about African writers on the world literary stage and has been described, on many occasions, as "Chinua Achebe's $21^{\text {st }}$-century daughter" (Uwakweh 53). There is undoubtedly much continuity between her work and that of her celebrated literary predecessor who, having written his groundbreaking first novel, Things Fall Apart, in 1958, came to be known as one of the "fathers of African literature". Adichie has frequently highlighted the fact that before reading Things Fall Apart she did not know that people like herself could exist in books ("A Tribute to Chinua Achebe" n. pag.). In this regard, she has also stressed that reading Achebe's work meant discovering that her African stories, those in which "girls with skin the color of chocolate, whose kinky hair could not form ponytails" ("The Danger of a Single Story" n. pag.) were included as main characters, could also become part of literature. When studying her writing, it is therefore important to take into account Achebe's imprint. However, although Adichie has often acknowledged that Achebe's stories about Africa and Africans had an enormous influence on her narrative, she has likewise pointed out that she has her personal individual style. Her first two novels, Purple Hibiscus (2003), for which she received the Commonwealth Writers' Best First Book Prize in 2005, and Half of a Yellow Sun (2006), for which she was awarded the Orange Broadband Prize for Fiction (2007), are both set in her home country, Nigeria, and, as in the case of Achebe's works, include many references to her Igbo cultural and linguistic background. On the other hand, her collection of short stories, The Thing Around Your Neck (2009), is set partly in Nigeria and partly in the United States, and her novel, Americanah, first published in 2013, recounts the journeys made by its protagonists, Ifemelu, who travels from Nigeria to America and back, and Obinze, who travels from 
Nigeria to the United Kingdom and back. All of Adichie's work has been greatly influenced by the experiences that she has had and her position as what she has referred to as "an inhabitant of the periphery":

Citizenship goes beyond a mere passport, it is a sensibility [...] Citizenship for a person like me, from a country like Nigeria, in a continent like Africa, is not just a sensibility, it is also a condition. A condition that arises from being what I like to call 'inhabitants of the periphery'. And what do I mean by 'inhabitants of the periphery?' I am not merely referring to political expressions like 'Third World', but to the phenomenon of being outside of the centre in ways more subtle than mere politics, in ways metaphysical and psychological $[. .$.$] We are a people conditioned by our history and$ by our place in the world to look somewhere else for validation. (Adichie, "The Writer as Two Selves" n. pag.)

The condition that Adichie describes in this extract has again been underlined by Paul Bandia, from Concordia University, Canada, not only in one of his latest works, "Translocation: Translation, Migration and the Relocation of Cultures", but also in a recently published interview in which he highlights the fact that African writers in many cases need to "translocate" themselves, physically and psychologically, in order to be read and translated in the West: "For me, 'translocation' is a reality in the writing practice of peripheral or minority literature to seek a space within the global literary context. It is not just a matter of choosing in what language to write. Themes, writing style, trends and, in some cases, physical movement or displacement are important" (Bandia, "An Interview" 150).

As has already been mentioned, Adichie's book of short stories, The Thing Around Your Neck, and her most recent novel, Americanah, are set in different places: Nigeria, the United Kingdom and America. In this sense, her work may be defined as "New Transatlantic African Writing", following a long tradition of African writers in whose literary productions transatlantic stories have featured as an important element. Moreover, her work may be included in what Nwosu and Obiwu define as "the project of globalizing the Igbo language and culture" (16). ${ }^{2}$ In this regard, although Adichie's experiences differ from those of her predecessors, "the diasporic consciousness" (Abalogu and Onyerionwu 233) is also present in her narrative. When analysing her writing, it is interesting to bear in mind that it was produced, in part, while she was living in the United States and this has always had a great influence 
on the content and style of her work. In relation to her first novel, Purple Hibiscus, she has explained: "I was living in Connecticut and hadn't been back to Nigeria for four years. I was intensely homesick. It was winter here and terribly cold. I looked out and saw this blanket of white and thought: 'I want home" (Adichie qtd. in Garner 4). The distance with respect to Nigeria, her country of origin, has made Adichie feel, as Rushdie puts it, "some sense of loss, some urge to reclaim, to look back" (10), which has led her to create "imaginary homelands" (ibid.). As she herself has mentioned in reference to Americanah, it is a novel that is as much about leaving home as returning and what it entails: "For me it is a novel about leaving home as much as it is about going back home, and really about what home means $[. .$.$] in that sense$ in which you leave home and you create home in your mind and then you go back and it is not what you have built up in your mind [...] there is a sense of loss [...]" (Adichie, "An Interview with "Americanah' Author" n. pag.).

Adichie's vast array of experiences is very evident in her writing, where she recounts her characters' transatlantic journeys while drawing many and varied diasporic images (Abalogu and Onyerionwu 240). Without a doubt, in Adichie's literary production, as well as in that of many authors of her generation, her diasporic, or, in Brancato's terms, "afrosporic" position (12), has been a major influence. Her situation has certainly afforded her "the necessary detachment towards her own personal background that enables her to confront and begin to deal with her country's bitter history" (Walder 125). Furthermore, not only has it allowed her to write about Nigeria from a distance, that is, analyse the situation of her country and her people from a global perspective, but also to describe new ways of defining what being African is. Adichie has often emphasized the fact that when she arrived in the US she began to see herself as African and Black, but before arriving in the US she was not aware of these identities: "I think that identity is such an interesting thing [...] Identity shifts based on where one is, really [...] When I came to the US, I found myself taking on a new identity. No, rather, I had a new identity thrust upon me. I became black in America and I really hadn't thought of myself as black in Nigeria" (Adichie, "An Interview with 'Americanah' Author" n. pag.).

\section{The Thing Around Your Neck and Americanah}

As previously stated, one of the images of the diaspora that Adichie draws in 
her fiction is that of a place where identities are ever-changing, a place where new identities arise while previous identity positions may be questioned. This becomes apparent in her novel, Americanah, where Ifemelu, one of the main characters, describes the manner in which she is defined as "black" in America. For instance, this is part of the blog that Ifemelu writes at different points in the novel3:

To My Fellow Non-American Blacks: In America, You Are Black, BABY

Dear Non-American Black, when you make the choice to come to America, you become black. Stop arguing. Stop saying I'm Jamaican or I'm Ghanaian. America doesn't care. So what if you weren't 'black' in your country? You're in America now. We all have our moments of initiation into the Society of Former Negroes. ( $A M$ 220)

Another image of the diaspora that can be found in Adichie's narrative is that of a place where many of her Nigerian characters feel the need to try and erase their Nigerian identity in order to fit into American society. As Abalogu and Onyerionwu affirm: "Adichie's exploration of the concept of alienation is subtle; with the full complement of satire and caricature. She realizes this in the form of a derisive attack on [...] the Nigerians who are sufficiently enchanted with especially the American culture, ethos and mannerisms to the extent of proposing a substitution of their own" (241). In fact, the title Americanah is a clear reflection of this phenomenon. The term "Americanah" is a Nigerian English word that makes reference to those Nigerians who try to change their Nigerian identity in order to become a part of American society. For example, in one of the stories included in The Thing Around Your Neck, "The Arrangers of Marriage", Adichie describes the way in which one of the characters, Ofodile, focuses on erasing his Nigerian identity as well as that of his wife, Chinaza, who he tries to "Americanize" when she arrives in the US, following a marriage arrangement previously made in Nigeria. Among other strategies, Ofodile resorts to choosing different names for each of them, Dave and Agatha, names that would seem more "appropriate" in the American context:

"I'm not called Ofodile here, by the way. I go by Dave", he said [...]

"Dave?" I knew he didn't have an English name. The invitation cards to our wedding had read Ofodile Emeka Udenwa and Chinaza Agatha Okafor. "The last name I use here is different, too. Americans have a hard time with 
Udenwa, so I changed it." [...] "It's Bell".

When he filled out a Social Security number application for me the next day, the name he entered in bold letters was AGATHA BELL. (TA 172173)

Another tactic which Ofodile chooses when erasing his and his wife's Nigerian identity is a deliberate and specific use of language. Hence, as well as avoiding certain terms and expressions particular to Nigerian English and the vernacular languages of Nigeria, he also makes an effort to use American English; this is illustrated in the following example:

We went into Macy's [...] My new husband led the way toward a sliding staircase; its movement was rubbery-smooth and I knew I would fall down the moment I stepped on it.

"Biko, don't they have a lift instead?" I asked [...]

"Speak English. There are people behind you", he whispered [...] "It's an elevator, not a lift. Americans say elevator". (TA 177)

For Adichie there is not one "Single Story" about what being African is, something she clearly points out in her well-known TED talk, "The Danger of a Single Story". In her work, she regularly insists on the idea that the African identity is always in the making. As a matter of fact, her African characters' transatlantic journeys imply a constant movement between several linguistic and cultural backgrounds which result in cultural and linguistic translation. For instance, although she speaks English, Americanah's main character, Ifemelu, describes the way in which, on arriving in America, she needs to become accustomed to those new terms and expressions specific to the American context:

She hungered to understand everything about America, to wear a new, knowing skin right away: to support a team at the Super Bowl, understand what a Twinkie was and what sports 'lockouts' meant, measure in ounces and square feet, order a 'muffin' without thinking that it really was a cake, and say "I 'scored' a deal" without feeling silly. ( $A M$ 135)

In several of her stories, Adichie's characters are faced, as "translated beings", with the need to translate their typical Nigerian dishes in order to adapt them to American ingredients. In this way, Nkem, the protagonist of the story 
"Imitation", resigns herself to using Uncle Ben's rice to make the Nigerian dish "jollof rice" and American potatoes instead of yams to cook her "ji akwukwo" pottage (TA 32). As well as these Nigerian dishes, and others like "fried plantains", "suya", "garri", "chin-chin", "okpa", or "pepper soup", in Adichie's writing one can find different Igbo, Nigerian English and Nigerian Pidgin 4 terms that describe other cultural references to the Nigerian environment. In this sense, it is interesting to draw attention to the fact that, although her books are written in English, Adichie manages to register "cultural difference" 5 (Bhabha 6o) in her texts through a specific use of language. Consequently, it may be said that the stories are a result of a creative type of "cultural translation" (163) through which "hybrid sites of meaning open up" (163) and an extensive cultural background is skilfully conveyed.

When referring to the use of "english" in postcolonial literature, Ashcroft, Griffiths and Tiffin have stressed that "[ $\mathrm{t}]$ he most interesting feature of its use in post-colonial literature may be the way in which it $[\ldots]$ constructs difference, separation, and absence from the metropolitan norm" (43). As I have mentioned elsewhere (Traducción y literatura africana (Translation and African Literature)), we could apply the same logic to Adichie's transcultural narrative, in which we could actually say that one of the most interesting features of the use of the English language in transcultural literature is the way it constructs difference, separation and also absence from the global norm. From this point of view, local uses of English, that is, local world views expressed in English, challenge the authority of English as a global language. Global grammatical norms are thus modified by local cultural conditions.

In The Thing Around Your Neck and Americanah, the reader can appreciate a tension between the global and the local, a negotiation between global and local identities, in the use of Nigerian linguistic and cultural markers within the text. Adichie describes herself as belonging to the Engli-Igbo generation of Nigeria and this shows in her works, where what could be defined as a "transcultural form of English" is employed: "I want to capture a sort of Nigerian Englishness [in my work] [...] It is not just that I want to write about characters who speak both Igbo and English [...] I want to capture that, but also, there is a kind of Nigerian English that has its own syntax, that to an ear that is not used to it can sometimes sound a bit awkward" (Adichie, "Chimamanda Ngozi Adichie: Tenement Talk" n. pag.). Adichie, as well as other members of her generation, no longer considers the English language as a colonial inheritance, but rather as a transcultural element that is now part and parcel of the Nigerian linguistic landscape and an important tool 
within the global literary space. Born into the Igbo ethnic community, in many instances Adichie makes use of the Igbo language in order to transmit a wide range of her Igbo characters' emotions, as one can observe in the following examples taken from The Thing Around Your Neck and Americanah:

And when he told her, she placed both hands on her head and cried, "Oh! Oh! Chi m egbuo m! My God has killed me!" (TA 4)

"It is rumpled. Ngwa, go and iron it ... Or change into something else". ( $A M 49)$

The Igbo language is certainly fundamental in Adichie's narrative. However, despite belonging to the Igbo ethnic group, she also incorporates into her work other languages which are used by Nigerians in their daily encounters through diverse writing strategies and descriptions:

There were the blind beggars led by children, singing blessings in English, Yoruba, pidgin, Igbo, Hausa when somebody put money in their plates. (TA 130)

"We're entering University City, and that's where Wellson campus is, shay you know? ..." Ginika had lapsed into Nigerian English, a dated, overcooked version, eager to prove how unchanged she was. ( $A M$ 123)

In this way, her specific usage of English draws on global and local resources, allowing for the expression of hybrid realities and identities. Throughout her different stories, Adichie speaks from various identity positionings, which cohabitate and interact in complex ways, and she therefore manages to challenge the global from varied localities: "I find it reductive that the different identity labels we carry must somehow be arranged in some sort of ascending or descending order. I am Igbo [...] I am Nigerian [...] I am African [...] I am all of these and more at the same time" (Adichie, "African 'Authenticity' and the Biafran Experience" 48-49).

\section{Conclusion}

Taking all of these observations into consideration, it is important to insist 
on the fact that Adichie does speak from different identity positionings: as an Igbo, as a Nigerian, as an African, as an African woman, as a migrant living between Nigeria and America, etc. And from these many shifting localities she manages to question not only diverse stereotypes or what she defines as "single stories" about what being African is, but also concepts such as identity, nation, home, territory, and African literature.

Given that some of the stories included in The Thing Around Your Neck and Americanah are set in the United States, many of Adichie's readers are faced with having to understand what is familiar in their everyday lives through the lens of a foreigner. In this regard, what may be common practice in the lives of some may be a cultural shock to Others. Adichie adeptly queries Western ways of perceiving and defining the African Other from the position of different and diverse characters and, at the same time, the distance from Nigeria allows her to reflect upon her culture of origin. Throughout the collection of stories and novel there is therefore "cultural translation" as well as linguistic translation, which constitutes a challenge to the reader on many levels and, through storytelling, allows for a better understanding of one another.

\section{Notes}

1. This article is part of a research project entitled "Violencia simbólica y traducción: retos en la representación de identidades fragmentadas en la sociedad global" (Symbolic Violence and Translation: Challenges in the Representation of Fragmented Identities within the Global Society) (FFI2015-66516-P; MINECO/FEDER, UE), financed by the Spanish Ministry of Economy and Competitiveness.

2. "In spite of the peculiar circumstances of his enslavement Equiano's book arguably launched that project of globalizing the Igbo over two hundred years earlier when, in repeatedly proclaiming his Igbo-African heritage, it became the most edited best-selling slave narrative in the world [...] That globalization continued with the emergence of Achebe's Things Fall Apart as a great African and world classic, and the recognition of such Igbo female novelists as Buchi Emecheta and Chimamanda Ngozi Adichie [...]." (Nwosu and Obiwu 16)

3. In the following examples, $A M$ stands for Americanah and TA for The Thing Around Your Neck.

4. As Igboanusi highlights: "In spite of the fact that Nigerian Pidgin (NP) is probably the language with the highest population of users in Nigeria, it does not enjoy official recognition and is excluded from the education system [...] Of the 400 languages used in Nigeria, Hausa, Igbo, and Yoruba are recognised as national languages. English is the official language while French is recognised as Nigeria's second official language. The remaining indigenous languages are recognised as minority languages" (68-69).

5. "[C]ultural difference as an enunciative category; opposed to relativistic notions of cultural diversity, or the exoticism of the 'diversity' of cultures. It is the 'between' that is 


\section{ELENA RODRÍGUEZ MURPHY}

articulated in the camouflaged subversion of the 'evil eye' and the transgressive mimicry of the "missing person"' (Bhabha 6o).

\section{Works Cited}

Abalogu, Allwell and Ezechi Onyerionwu. Chimamanda Ngozi Adichie. The Aesthetics of Commitment and Narrative. Ibadan: Kraft Books, 2010. Print.

Adichie, Chimamanda N. Purple Hibiscus. London/New York: Harper Perennial, 2005 (2003). Print.

--.. "African 'Authenticity' and the Biafran Experience." Transition, vol. 99. 2008: 42-53. Print.

---. "Chinua Achebe: A Tribute to Chinua Achebe." Pen American Center. 26 Feb. 2008. Web. 23 May 2017. <http://www.pen.org/book/chinua-achebea-tribute-to-chinua-achebe>.

---. The Thing Around Your Neck. London: Fourth Estate, 2009. Print.

---. "The Danger of a Single Story." Ted Talk. 22 Jul. 2009. Web. 23 May 2017. $<$ http://www.ted.com/talks/chimamanda_adichie_the_danger_of_a_ single_story.html>.

---. "The Writer as Two Selves: Reflections on the Private Act of Writing and the Public Act of Citizenship." Princeton University. 20 Oct. 2010. Web. 30 Nov. 2016. <http://www.princeton.edu/WebMedia/flash/lectures/20101020_ publect_adichie.shtml>.

--.. Americanah. London: Fourth Estate, 2014 (2013). Print.

--. "Chimamanda Ngozi Adichie: Tenement Talk." Tenement Talks 2014. 12 March 2014. Web. 30 Nov. 2016. <https://www.youtube.com/watch?v=yY1RK6aAPws>.

--.. "An Interview with 'Americanah' Author Chimamanda Ngozi Adichie." Interview by Michele Norris. 2014 Washington Ideas Forum. 30 Nov. 2014. Web. 23 May 2017. <http://library.fora.tv/2014/10/3o/interview_ chimamanda_ngozi_adichie_author_americanah>.

Ashcroft, Bill, Gareth Griffiths and Helen Tiffin. The Empire Writes Back. Theory and Practice in Post-Colonial Literatures. London/New York: Routledge, 1989. Print.

Bandia, P. F. "Translocation: Translation, Migration and The Relocation of Cultures." A Companion to Translation Studies. Eds. S. Bermann and C. Porter. Chichester: Wiley-Blackwell, 2014. 273-284. Print.

---. "An Interview with Professor Paul Bandia." Interview by Elena Rodríguez Murphy. Perspectives. Studies in Translatology, vol. 23, no. 1. 2015: 143-154. Print. 
Bhabha, Homi. The Location of Culture. London/New York: Routledge, 1994. Print.

Brancato, Sabrina. Afro-Europe. Texts and Contexts. Berlin: Trafo, 2009. Print.

Garner, Clare. "Profile of Chimamanda Ngozi Adichie." Purple Hibiscus. Chimamanda N. Adichie. London/New York: Harper Perennial, 2005 (2003). 1-17. Print.

Gikandi, Simon, ed. Encyclopedia of African Literature. London/New York: Routledge, 2003. Print.

Hale, Thomas A. "Bursting at the Seams: New Dimensions for African Literature in the 21st Century." New Directions in African Literature. Ed. Ernest N. Emenyonu. Oxford: James Currey, 2006. 10-21. Print.

Igboanusi, Herbert. "Empowering Nigerian Pidgin: a challenge for status planning?" World Englishes, vol. 27, no. 1. 2008: 68-82. Print.

Nwosu, Maik and Obiwu, eds. The Critical Imagination in African Literature: Essays in Honor of Michael 7. C. Echeruo. New York: Syracuse University Press, 2014. Print.

Obiechina, Emmanuel N. Language and Theme: Essays on African Literature. Washington, D.C.: Howard University Press, 1990. Print.

Rodríguez Murphy, Elena. Traducción y literatura africana: multilingüismo y transculturación en la narrativa nigeriana de expresión inglesa (Translation and African Literature: Multilingualism and Transculturation in Anglophone Nigerian Writing). Granada: Comares, 2015. Print.

Rushdie, Salman. Imaginary Homelands. Essays and Criticism 1981-1991. London: Granta Books, 1991. Print.

Uwakweh, Pauline A. "Breaking Gods. The Narrator as Revelator and Critic of the Postcolonial Condition in Purple Hibiscus." Emerging African Voices. A Study of Contemporary African Literature. Ed. Walter P. Collins. Amherst/ New York: Cambria Press, 2010. 53-74. Print.

Walder, Dennis. Postcolonial Nostalgias: Writing, Representation and Memory. London: Routledge, 2011. Print.

ELENA RODRÍGUEZ MURPHY holds a Ph.D. in Translation Studies from the University of Salamanca (Spain), where she works as a part-time professor in the Department of Translation and Interpreting. Her research interests are African literatures, Translation Studies and Linguistics. She has published several articles and book chapters on these areas of study, including 
"An Interview with Sefi Atta" (2012), published in the journal Research in African Literatures, and "An Interview with Professor Paul Bandia" (Perspectives, 2015). She is the author of Traducción y literatura africana: multilingüismo $y$ transculturación en la narrativa nigeriana de expresión inglesa (Translation and African Literature: Multilingualism and Transculturation in Anglophone Nigerian Writing) (Granada: Comares, 2015). er.murphy@usal.es 